\title{
Hubungan Kualitas Tidur dan Tingkat Kemandirian Activity of Daily Living dengan Risiko Jatuh Pada Lanjut Usia di Puskesmas Simpang IV Sipin Kota Jambi
}

\author{
Mashudi \\ Jurusan Keperawatan Poltekkes Jambi \\ Correspondence email: mashudi27@yahoo.com
}

\begin{abstract}
Abstrak. Sensus penduduk tahun 2010 jumlah lansia yang berusia 60 tahun keatas adalah \pm 18 juta jiwa atau 7,6\% dari total penduduk. Pada tahun 2014, jumlah penduduk lansia menjadi 18,781 juta jiwa. Bertambahnya jumlah penduduk lansia di Indonesia berdampak pada meningkatnya permasalahan pada kelompok lansia. Berbagai keterbatasan akibat penurunan fungsi dan perubahan anatomis tubuh serta proses penyakit meningkatkan risiko lansia mengalami jatuh. Penelitian ini menggunakan metode survei analitik dengan rancangan cross sectional, bertujuan untuk mengetahui hubungan kualitas tidur dan tingkat kemandirian dalam Activity of Daily Living dengan risiko jatuh pada lansia di puskesmas Simpang IV Sipin Kota Jambi. Pengumpulan data menggunakan kuesioner dan lembar observasi. Jumlah sampel sebanyak 95 orang lansia dengan teknik accidental sampling. Analisis data menggunakan uji chi-square. Hasil analisis chi-square didapatkan ada hubungan bermakna antara kulitas tidur dengan risiko jatuh ( $p$-value $=0,000)$ dan ada hubungan bermakna antara tingkat kemandirian dalam Activity of Daily Living (ADL) dengan risiko jatuh ( $p$-value $=0,007$ ). Perawat dapat mengedukasi lansia bagaimana mencegah jatuh dengan mengajarkan teknik yang aman untuk berpindah, mengambil sesuatu secara tepat, membungkuk, menghindari gerakan yang tergesa-gesa atau mendadak, waktu beraktivitas yang tepat, dan penggunaan obat yang benar.
\end{abstract}

Kata Kunci: kualitas tidur; tingkat kemandirian dalam ADL; risiko jatuh

\begin{abstract}
The census of the population of 2010 years old aged 60 years and above is \pm 18 million people or $7.6 \%$ of the total population. In 2014, the population was 18.781 million. The increasing number of elderly people in Indonesia has impacted the increasing problems in elderly groups. Various limitations due to decreased function and the anatomical changes in the body as well as disease processes increase the risk of elderly falls. This study uses a cross sectional analytical method of analytics survey, aims to determine the relationship of sleep quality and the level of self-reliance in the Activity of Daily Living with the risk of falling in the elderly at the Puskesmas Sipin Simpang IV city Center Jambi. Data collection using questionnaires and observation sheets. Sample amount of 95 elderly people with accidental sampling technique. Data analysis using Chi-square test. The results of the chi-square analysis have a meaningful relationship between the sleep and the risk of falling $(p$-value $=0.000)$ and there is a meaningful relationship between the degree of self-reliance in the Activity of Daily Living (ADL) with a falling risk ( $p$-value $=$ 0.007). Nurses can educate the elderly how to prevent falling by teaching safe techniques to move, precisely pick up, bend down, avoid hasty or sudden movements, proper activity time, and the use of The correct medication.
\end{abstract}

Keywords: sleep quality; level of independence in ADL; risk of falling

\section{PENDAHULUAN}

Jumlah lansia saat ini terus bertambah, bahkan WHO memperkirakan pada tahun 2025 jumlah lansia diseluruh dunia dapat mencapai 1,2 miliar dan $75 \%$ dari jumlah lansia tersebut berada di negara berkembang, akan terus bertambah menjadi 2 miliar pada tahun 2050 . Data World Population Prospects : the 2015 Revision, pada tahun 2015 ada 901 juta orang berusia 60 tahun atau lebih yang merupakan $12 \%$ dari penduduk dunia saat ini. Pada tahun 2015 dan 2030, jumlah orang berusia 30 tahun atau lebih diproyeksikan akan tumbuh sekitar 56 persen, dari 901 juta menjadi 1,4 milyar.United Nation tahun 2015, menyebutkan bahwa Asia me-nyumbangkan 56 persen dari total populasi lansia di dunia yaitu sebanyak 508 juta populasi lansia (Potter PA, 2006; Jayanti IGP, 2016).

Bila mengacu pada batasan lansia yang dihitung dari usia 60 tahun, maka di Indonesia kelompok penduduk berusia 60 tahun ke atas pada tahun 2000 berjumlah 14,8 juta jiwa atau 7,2\%. Peningkatan persentase penduduk usia 60 tahun keatas antara tahun 1990-2000 diperkirakan sebesar 0,9\%. Sensus penduduk tahun 2010 jumlah lansia yang berusia 60 tahun keatas adalah \pm 18 juta jiwa atau 7,6\% dari total penduduk. Pada tahun 2014, jumlah penduduk lanjut usia menjadi 18,781 juta jiwa. Pada tahun 2020 jumlah lansia di Indonesia diproyeksikan sebesar $11,34 \%$. Suatu negara dikatakan berstruktur tua jika mempunyai populasi lansia di atas tujuh persen, hal ini berarti Indonesia termasuk kedalam kelompok negara berstruktur tua. Kemenkes RI tahun 2015, menyebutkan bahwa Indonesia termasuk dalam lima besar negara dengan jumlah lansia terbanyak di dunia (Sekjen Kemenkes RI, 2015; Tamher S, 2009; Maryam RS, dkk, 2008).

Sensus penduduk pada tahun 2010 di Provinsi Jambi penduduk yang berusia 60 tahun ke atas berjumlah 170.369 atau 5,5\%. Sementara pada tahun 2012 jumlahnya sudah mencapai 178.302 jiwa lansia 
atau 5,6\% dari 3,1 juta jiwa penduduk provinsi Jambi. Peningkatan Usia Harapan Hidup (UHH) dan semakin membaiknya sarana kesehatan berperan dalam peningkatan jumlah lansia setiap tahunnya di provinsi Jambi (Supriyadi E, 2014).

Penuan saat ini menjadi fenomena yang mendominasi dalam masyarakat. Gambaran mengenai penduduk lansia yang kurang aktif dan mengalami penyakit kronis kini digantikan dengan konsep baru, yaitu lansia yang mampu beradaptasi dengan proses penuaan serta penurunan angka morbiditas berupa penundaan awitan terjadinya suatu penyakit hingga tahap akhir kehidupan. Pencegahan untuk individu berusia 60 tahun ke atas yang diharapkan hidup hingga 20 tahun lagi merupakan kompetensi penting yang harus dimiliki oleh perawat profesional khususnya perawat lansia (Stanley M \& Berae PG, 2007).

Peran perawat sebagai salah satu tenaga kesehatan dibutuhkan dalam upaya mencapai kesejahteraan lansia di Indonesia. Perawat tidak hanya sebagai pemberi perawatan yang berkesinam-bungan, namun perawat bertindak sebagai pencegah komplikasi lebih lanjut dari penyakit yang diderita lansia serta berupaya mempertahankan dan mengoptimalkan fungsi normal yang masih dimiliki oleh lansia. Imobilisasi merupakan salah satu masalah kesehatan yang paling sering terjadi pada lansia. Imobilisasi dapat berdampak pada konsekuensi fisiologis dan psikologis yang serius. Menurut penelitian dari 10 sampai 15 persen kekuatan otot dapat hilang setiap minggu jika otot itu beristirahat sepenuhnya, dan sebanyak 5,5 persen dapat hilang setiap hari pada kondisi istirahat dan imobilisasi sepenuhnya. Pinggul, lutut, dan pergelangan kaki merupakan sendi yang sangat mudah terpengaruh oleh gravitasi. Hal ini semakin dipersulit dengan adanya kontraktur sehingga lansia menjadi kurang stabil dan menyebabkan lansia lebih sering mengalami jatuh (Stanley M \& Berae PG, 2007).

Jatuh adalah keadaan dimana seseorang yang dalam keadaan sadar tanpa disengaja berada di permukaan tanah atau lantai. Pada lansia, secara anatomis akan terjadi perubahan pada postur tubuh sehingga mempengaruhi keseim bangan dan gaya berjalan. Risiko jatuh meningkat seiring bertambahnya usia, rata-rata setiap tahun sepertiga lansia berusia 65 tahun ke atas pernah mengalami jatuh. Risiko jatuh menjadi hal yang ditakuti oleh lansia, apalagi lansia yang sudah pernah mengalami jatuh. Hampir 25\% lansia berusia 75 tahun atau lebih yang pernah jatuh takut bergerak aktif. Mereka akan takut untuk bergerak dan melakukan aktivitas dan memilih untuk berada di tempat tidur saja. Sehingga akan menurunkan status fungsional lansia dan meningkatkan ketergantungan dalam melakukan Activity Daily Living (ADL) (Stanley M \& Berae PG, 2007; Dewi SR, 2014).

Jatuh dapat mengakibatkan berbagai cidera tidak hanya kerusakan fisik namun juga akan berdampak terhadap psikologis. Cidera yang paling sering terjadi akibat jatuh ialah fraktur. Satu di antara 200 lansia berumur 65-69 tahun yang terjatuh mengalami patah tulang pinggul. Seperempat di antaranya meninggal akibat cedera ini dalam waktu 6 bulan. Cidera fisik yang didapatkan pasca kejadian jatuh dapat dibedakan berdasarkan berat ringannya cidera. Walaupun cidera fisik tidak terjadi, konsekuensi akibat kejadian jatuh yang tidak terduga akan meninggalkan trauma mental berupa syok setelah jatuh, rasa takut jatuh kembali, ansietas, kehilangan keperca-yaan diri, isolasi sosial, membatasi aktivitas, fobia jatuh dan hilangnya kemandirian (Stanley M \& Berae PG, 2007).

Kejadian jatuh bukanlah keadaan normal dari proses penuaan, meski hingga kini masyarakat kebanyakan masih menganggap jatuh sebagai konsekuensi alami menjadi tua. Upaya pencegahan jatuh lebih penting dari pada harus mengobati konsekuensi yang terjadi akibat jatuh pada lansia. Saat ini pengeluaran yang harus ditanggung negara untuk orang yang berusia 60 tahun keatas hampir 4 kali lipat dari pada pasien dalam kelompok umur lebih muda. Bukan tidak mungkin apabila jumlah lansia yang terus bertambah tanpa diikuti dengan upaya untuk mensejahterakan hidup masyara-kat di usia senja maka tanggungan yang akan dikeluarkan negara akan lebih besar lagi dari angka yang terjadi saat ini. Sebagai tenaga kesehatan, perawat perlu mengetahui faktor risiko apa saja yang meningkatkan risiko jatuh pada lansia.

Jatuh dapat terjadi baik oleh faktor dari lansia sendiri maupun dari lingkungan-nya. Adapun upaya pencegahan jatuh yang dapat dilakukan oleh perawat yaitu dengan memperbaiki gangguan keseim-bangan dengan membuat lansia tetap aktif dalam melakukan aktivitas dan kebutuhannya sehari-hari (Stanley M \& Berae PG, 2007; Dewi SR, 2014).

Aktivitas kehidupan sehari-hari atau yang dikenal dengan ADL merupakan aktivitas primer dalam perawatan diri. Pengkajian ADL sangat penting untuk mengetahui tingkat kemandirian lansia. Pada lansia yang risiko jatuh atau yang sudah pernah mengalami jatuh, mereka akan takut untuk memenuhi semua kebutuhan ADL dan membatasi aktivitasnya. Ketika aktivitas, mobilitas, dan kemandirian dibatasi maka penurunan fungsi mulai terjadi. Jadi sangat penting untuk mempertahankan fungsi normal pada lansia. Hasil penelitian mengenai gangguan status fungsional pada lansia baik secara fisik maupun psikologis menunjukkan adanya hubungan dengan adanya penyakit pada lansia ataupun penurunan status kesehatan. Status fungsional lansia harus dipertahankan semandiri mungkin untuk meningkatkan status kesehatan lansia (Tamher S, 2009; Stanley M \& Berae PG, 2007).

Salah satu aktivitas dalam meningkat-kan kesehatan adalah tidur. Tidur merupakan kebutuhan dasar manusia yang harus dipenuhi setiap orang. Dengan tidur yang cukup, tubuh akan berfungsi secara optimal. 
Secara fisiologis, jika seseorang tidak mendapat tidur yang cukup untuk mempertahankan kesehatan tubuh, maka dapat terjadi efek-efek merugikan seperti menjadi pelupa, konfusi, dan disorientasi, terutama jika deprivasi tidur terjadi dalam waktu yang lama. Pada sebagian besar lansia akan mengalami perubahan pola tidur yang mempengaruhi kualitas tidur akibat proses patologis penuaan. Gangguan tidur mempengaruhi kualitas hidup dan berhubungan dengan angka mortalitas yang lebih tinggi (Stanley M \& Berae PG, 2007; Mubarak WI, 2008).

Faktor usia merupakan faktor penting yang mempengaruhi kualitas tidur. Keluhan tidur muncul seiring dengan bertambahnya usia. Pada kelompok lansia (60 tahun) ditemukan 7\% kasus yang mengeluh mengenai kualitas tidur, mereka hanya bisa tertidur tidak lebih dari lima jam sehari. Kasus yang sama dialami kelompok usia 70 tahun sebanyak $22 \%$. Kelompok lanjut usia lebih banyak mengeluh terbangun lebih awal dari pukul 05.00. selain itu, sebanyak 30\% lansia berusia 70 tahun terbangun lebih awal pada malam hari. Perbandingan gangguan kualitas tidur yang diderita lansia dibandingkan dengan kelompok usia 20 tahun ialah 7:1 (Nugroho W, 2014).

Penelitian yang dilakukan oleh Nurma tahun 2015, ada hubungan bermakna antara kualitas tidur dengan tingkat keseimbangan pada lansia yang diteliti dengan nilai signifikansi $p=0,000$ dan koefisien korelasi $r=-0,621$. Penelitian Sutiahardja AS tahun 2005, ada hubungan bermakna dan korelasi yang kuat antara keseimbangan dengan ADL pada lansia dengan nilai $p=0,000$ dan nilai koefisien korelasi $r=0,779$. Semakin tua umur seseorang, sistem vestibular pada otak yang mengatur keseimbangan tubuh semakin menurun sensitivitasnya. Akibatnya pada lanjut usia akan semakin berisiko untuk jatuh. Oleh karena itu, peneliti tertarik untuk mengetahui apakah terdapat hubungan antara kualitas tidur dengan risiko jatuh pada lansia serta hubungan antara tingkat kemandirian dalam ADL dengan risiko jatuh pada lansia.

Dinas Kesehatan Kota Jambi mengurutkan sepuluh besar jumlah kunjungan lansia terbanyak berdasarkan data pencapaian hasil kegiatan kesehatan kelompok lansia di Kota Jambi tahun 2015. Dari sepuluh puskesmas tersebut, puskesmas Simpang IV Sipin menduduki urutan pertama dengan jumlah kunjungan 9021.

\section{METODE}

Penelitian ini menggunakan metode survei analitik dengan rancangan cross sectional, bertujuan untuk mengetahui hubungan kualitas tidur dan tingkat kemandirian dalam Activity of Daily Living dengan risiko jatuh pada lansia di puskesmas Simpang IV Sipin Kota Jambi. Pengumpulan data dilakukan tanggal 3-8 Oktober 2016 menggunakan kuesioner dan lembar observasi. Jumlah sampel sebanyak 95 orang lansia dengan teknik accidental sampling. Analisis data menggunakan uji chi-square.

Kualitas tidur dinilai dengan kuesioner kualitas tidur Pittsburgh Sleep Quality Index (PSQI) terdiri dari 16 pertanyaan yang meliputi 6 komponen yaitu latensi tidur, durasi tidur, kebiasaan tidur, gangguan tidur, penggunaan obat tidur, dan disfungsi siang hari. Kuesioner PSQI dalam terjemahan bahasa Indonesia telah dilakukan uji validitas dan reabilitas pada banyak penelitian mengenai kualitas tidur. Hasilnya menunjukkan bahwa pertanyaan-pertanyaan dalam kuesioner kualitas tidur PSQI dinyatakan valid. Begitu juga dengan uji reliabilitas dengan hasilnya termasuk dalam kriteria tinggi. Menurut penelitian yang dilakukan oleh Dini Dian Flowerenty (2015) dengan melakukan uji validitas kuesioner PSQI dengan menggunakan uji korelasi pearson product moment (r) mendapat-kan hasil yaitu $r$ tabel 0,444 dan $r$ hitung lebih dari $r$ tabel yaitu 0,556-0,880. Begitu pula dengan hasil uji reliabilitas dengan menggunakan cronbach's alpha diperoleh nilai sebesar 0,766 yang temasuk dalam kriteria tinggi.

Tingkat kemandirian responden diukur melalui wawancara dengan responden/ keluarga maupun caregiver mengguna-kan instrumen indeks katz. Indeks ini didasarkan pada hasil evaluasi terhadap tingkat kemandirian atau keadaan sebaliknya, yaitu tingkat ketergantungan secara fungsional. Indeks ini terdiri atas 7 tingkatan sebagai hasil dari penilaian 6 komponen aktivitas dasar sehari-hari seperti mandi, berpakaian, ke toilet, beranjak, kontinensia dan makan (Martono $\mathrm{H} \&$ Pranaka K, 2009). Indeks katz merupakan alat ukur yang sudah baku dengan nilai uji reliabilitas yang sangat tinggi yaitu $>0,95$ sehingga peneliti tidak melakukan uji validitas dan reliabilitas (Ningrum DNP, 2011).

Pengukuran risiko jatuh dilakukan melalui tehnik observasi langsung terhadap responden. Instrumen yang digunakan adalah kriteria timed up and go (TUG) dengan menggunakan perala-tan stopwatch untuk mengukur waktu tes, kursi, dan meteran. Tes TUG digunakan karena tes ini sederhana dan tidak membutuhkan banyak waktu. Peneliti tidak melakukan uji validitas dan reliabilitas karena tes ini merupakan alat uji standar dalam mengukur keseimbangan pada lansia yang banyak digunakan dalam penelitian-penelitian mengenai risiko jatuh.

\section{HASIL DAN PEMBAHASAN}

Memuat karakteristik responden, analisis univariat, dan analisis bivariat. Karakteristik responden selanjutnya dapat dilihat pada tabel berikut ini :

Tabel 1. Distribusi Frekuensi Responden Berdasarkan Jenis Kelamin di Puskesmas Simpang IV Sipin Kota Jambi Tahun 2016

\begin{tabular}{cccc}
\hline No. & Jenis Kelamin & Frekuensi & Persentase \\
\hline 1 & Laki-laki & 42 & 44,2 \\
2 & Perempuan & 53 & 55,8 \\
& Jumlah & 95 & 100 \\
\hline
\end{tabular}


Mashudi, Hubungan Kualitas Tidur dan Tingkat Kemandirian Activity of Daily Living dengan Risiko Jatuh Pada Lanjut Usia di Puskesmas Simpang IV Sipin Kota Jambi

Tabel 2. Distribusi Frekuensi Responden Berdasarkan Usia di Puskesmas Simpang IV Sipin Kota Jambi Tahun 2016

\begin{tabular}{cccc}
\hline No. & Usia Responden & Frekuensi & Persentase \\
\hline 1. & $60-63$ & 27 & 28,4 \\
2. & $64-67$ & 20 & 21,1 \\
3. & $68-71$ & 19 & 20,0 \\
4. & $72-75$ & 14 & 14,7 \\
5. & $76-79$ & 10 & 10,5 \\
6. & $80-83$ & 4 & 4,2 \\
7. & $84-87$ & 0 & 0 \\
8. & $88-91$ & 1 & 1,1 \\
& Jumlah & 95 & 100 \\
\hline
\end{tabular}

Analisis univariat bertujuan untuk mengidentifikasi kualitas tidur, tingkat kemandirian dalam ADL, dan risiko jatuh lansia. Selanjutnya dapat dilihat pada tabel berikut ini :

Tabel 3. Distribusi Frekuensi Responden Berdasarkan Kualitas Tidur di Puskesmas Simpang IV Sipin Kota Jambi Tahun 2016

\begin{tabular}{clcc}
\hline No. & Kualitas Tidur Lansia & Frekuensi & Persentase \\
\hline 1. & Baik & 36 & 37,9 \\
2. & Buruk & 59 & 62,1 \\
& $\quad$ Jumlah & 95 & 100 \\
\hline
\end{tabular}

Tabel 4. Distribusi Frekuensi Responden Berdasarkan Kemandirian ADL di Puskesmas Simpang IV Sipin Kota Jambi Tahun 2016

\begin{tabular}{clcc}
\hline No. & Tingkat ADL & Frekuensi & Persentase \\
\hline 1. & Mandiri & 54 & 56,8 \\
2. & Tidak mandiri & 41 & 43,2 \\
& Jumlah & 95 & 100 \\
\hline
\end{tabular}

Tabel 5. Distribusi Frekuensi Responden Berdasarkan Risiko Jatuh di Puskesmas Simpang IV Sipin Kota Jambi Tahun 2016

\begin{tabular}{cccc}
\hline No. & Risiko Jatuh & Frekuensi & Persentase \\
\hline 1. & Tidak berisiko & 33 & 34,7 \\
2. & Berisiko & 62 & 65,3 \\
& Jumlah & 95 & 100 \\
\hline
\end{tabular}

Analisis bivariat bertujuan untuk mengidentifikasi apakah ada hubungan antara kualitas tidur dan kemandirian dalam ADL dengan risiko jatuh lansia di Puskesmas Simpang IV Sipin. Selanjutnya dapat dilihat pada tabel berikut ini:

Tabel 6. Analisis Hubungan Kualitas Tidur Dengan Risiko Jatuh Lansia di Puskesmas Simpang IV Sipin Kota Jambi Tahun 2016

\begin{tabular}{|c|c|c|c|c|c|c|c|}
\hline \multirow{3}{*}{$\begin{array}{c}\text { Kualitas } \\
\text { Tidur }\end{array}$} & \multicolumn{4}{|c|}{ Risiko Jatuh } & \multirow{2}{*}{\multicolumn{2}{|c|}{$\begin{array}{c}\text { Total } \\
\%\end{array}$}} & \multirow{3}{*}{$\begin{array}{c}P- \\
\text { value }\end{array}$} \\
\hline & \multicolumn{2}{|c|}{$\begin{array}{l}\text { Tidak } \\
\text { berisiko }\end{array}$} & \multicolumn{2}{|c|}{ Berisiko } & & & \\
\hline & $\mathrm{N}$ & $\%$ & $\mathrm{~N}$ & $\%$ & $\mathrm{~N}$ & $\%$ & \\
\hline Baik & 21 & 58,3 & 15 & 41,7 & 36 & 100 & \multirow{3}{*}{0,000} \\
\hline Buruk & 12 & 20,3 & 47 & 79,7 & 59 & 100 & \\
\hline Jumlah & 33 & 34,7 & 62 & 65,3 & 95 & 100 & \\
\hline
\end{tabular}

Dari tabel 6 dapat disimpulkan bahwa ada hubungan yang signifikan antara kualitas tidur dengan risiko jatuh lansia di Puskesmas Simpang IV Kota Jambi.

Tabel 7. Analisis Hubungan Tingkat Kemandirian dalam ADL Dengan Risiko Jatuh Lansia di Puskesmas Simpang IV Sipin Kota Jambi Tahun 2016

\begin{tabular}{lccccccc}
\hline \multirow{2}{*}{$\begin{array}{c}\text { Tk. } \\
\text { Kemandirian }\end{array}$} & \multicolumn{4}{c}{$\begin{array}{c}\text { Risiko Jatuh } \\
\text { didak }\end{array}$} & \multicolumn{2}{c}{ Berisiko } & \multicolumn{2}{c}{$\begin{array}{c}\text { Total } \\
\%\end{array}$} & $\begin{array}{c}\text { P- } \\
\text { value }\end{array}$ \\
\cline { 2 - 8 } & $\mathrm{N}$ & $\%$ & $\mathrm{~N}$ & $\%$ & $\mathrm{~N}$ & $\%$ & \\
Mandiri & 21 & 58,3 & 15 & 41,7 & 36 & 100 & 0,000 \\
Tdk mandiri & 12 & 20,3 & 47 & 79,7 & 59 & 100 & \\
Jumlah & 33 & 34,7 & 62 & 65,3 & 95 & 100 & \\
\hline
\end{tabular}

Dari tabel 7 dapat disimpulkan bahwa ada hubungan yang signifikan antara kemandirian dalam melakukan ADL dengan risiko jatuh pada lansia di Puskesmas Simpang IV Sipin Kota Jambi.

\section{Pembahasan}

Hubungan kualitas tidur dengan risiko jatuh pada lansia Berdasarkan tabel 6, hasil analisis hubungan kualitas tidur dengan risiko jatuh pada lansia di Puskesmas Simpang IV Sipin Kota Jambi diketahui bahwa ada hubungan bermakna antara kualitas tidur dengan risiko jatuh pada lansia ( $p$-value $=0,000)$. Penelitian ini sejalan dengan penelitian Nurma Dwi Sulistyarini (2015), yang menyatakan bahwa ada hubungan yang bermakna antara kualitas tidur dengan tingkat keseimbangan tubuh lansia dengan nilai signifikasi $p=0,000$.

Secara psikologis, dengan tidur seseorang akan merasakan perasaan sejahtera, energi kembali setelah beraktivitas yang menguras energi, serta kesiapan untuk melaksanakan tugas-tugas. Kinerja, kewaspadaan, angka aktivitas, dan kesehatan dipengaruhi oleh pola tidur dan bangun yang terganggu. Sebuah teori menyebutkan bahwa lamanya periode tidur dapat mempengaruhi tingkat mortalitas. Studi selama 6 tahun mendukung hipotesis bahwa orang yang tidur tidak efektif atau dalam waktu lama ataupun singkat serta penggunaan pil tidur, mengalami angka mortalitas lebih tinggi dibanding kan mereka yang tidur dengan waktu yang efektif (Stanley M \& Berae PG, 2007).

Hampir sepertiga usia manusia dihabiskan untuk tidur. Kebutuhan akan tidur hampir sama pentingnya dengan kebutuhan makan dan minum. Tidur yang lelap dan nyenyak tanpa adanya gangguan menjadi sangat penting. Karena gangguan terhadap tidur malam hari menyebabkan seseorang mengan-tuk sepanjang hari dan mengganggu aktivitas disiang hari. Sementara itu, semakin bertambahnya usia seseorang akan kehilangan waktu tidur yang nyenyak. Inilah alasan mengapa pada lansia sering mengalami gangguan tidur ataupun kualitas tidur yang buruk.

Kualitas tidur yang buruk berisiko menyebabkan terjadinya kecelakaan, jatuh, penurunan stamina, dan 
penurunan produktivitas lansia tersebut. Dapat pula terjadi ketidakbahagiaan, perasaan kesepian, dan memburuknya suatu penyakit degeneratif yang telah diderita sebelumnya. Hal inilah yang akhirnya menjadi penyebab mengapa seorang lansia berisiko untuk mengalami kecelakaan atau cedera dalam hal ini risiko jatuh (Martono H \& Pranaka K, 2009).

Penurunan aktivitas akan berdampak pada status fungsional lansia dimana pada keadaan istirahat yang berkepanja-ngan akan menurunkan kekuatan otot dan menyebabkan gangguan keseim bangan (Sekjen Kemenkes RI, 2015; Stanley M \& Berae PG, 2007). ${ }^{3,7}$ Hal ini sesuai dengan teori mengenai fungsi tidur itu sendiri, dimana terdapat hubungan berbagai fungsi tubuh seperti penampilan motorik, memori, dan keseimbangan yang berubah ketika terjadi kehilangan tidur yang memanjang (Potter PA, 2006).

Perawat dapat melakukan upaya pencegahan dan membantu lansia untuk memperoleh pola tidur yang efektif. Mengidentifikasi gangguan tidur yang mungkin diderita oleh lansia penting untuk menentukan tindakan yang dibutuhkan sesuai keluhan yang dialami lansia. Perawat dapat memberikan edukasi mengenai hal atau kebiasaan yang dapat dilakukan ataupun yang tidak perlu dilakukan sebelum memulai tidur untuk membantu tidur lebih efektif (Stanley M \& Berae PG, 2007).

Peneliti menyarankan agar perawat dapat memberikan edukasi pada lansia mengenai pentingnya menjaga kualitas tidur yang baik, perawat perlu bekerjasama melibatkan keluarga dalam memberikan edukasi untuk menyelesai-kan masalah gangguan tidur pada lansia.

\section{Hubungan tingkat kemandirian dalam melakukan $A D L$} dengan risiko jatuh pada lansia

Berdasarkan tabel 7, hasil analisis hubungan tingkat kemandirian dalam ADL dengan risiko jatuh pada lansia di Puskesmas Simpang IV Sipin Kota Jambi diketahui bahwa ada hubungan bermakna antara tingkat kemandirian dalam ADL dengan risiko jatuh pada lansia ( $p$-value $=0,007)$. Meskipun pada hasil penelitian lansia yang mandiri dalam ADL masih lebih tinggi frekuensi yang berisiko jatuh, perbandingan angka yang lebih signifikan terjadi pada lansia yang tidak mandiri. Adanya hubungan yang signifikan antara tingkat kemandirian dalam ADL dengan risiko jatuh pada penelitian ini dikarenakan perbandingan frekuensi lansia yang berisiko dan yang tidak berisiko cukup tinggi. Angka frekuensi lansia yang tidak berisiko hampir sebagian dari angka frekuensi lansia yang berisiko.

Penelitian ini sejalan dengan penelitian Yulinda Permata Sari (2015), dimana terdapat hubungan tingkat kemandirian dalam ADL dengan risiko jatuh pada lansia di PSTW Unit Budhi Luhur Kasongan Bantul Yogyakarta dengan nilai $p$-value $=0,000$. Sebaliknya penelitian ini bertentangan dengan penelitian Eka Ediawati (2012), yang menyatakan bahwa lansia dengan tingkat kemandirian tinggi memiliki risiko jatuh yang tinggi pula. Dalam penelitian tersebut peneliti berpendapat bahwa aktivitas dan lingkungan merupakan faktor yang berperan dalam terjadinya jatuh pada lansia. Semakin banyak aktivitas yang dilakukan oleh lansia semakin berisiko lansia tersebut untuk mengalami jatuh.

Kemandirian dalam ADL yang dihubungkan dengan risiko jatuh disini ialah kemampuan lansia untuk mandiri dan tetap bergerak aktif tanpa atau minim bantuan dari orang lain sehingga mobilitas lansia tetap terjaga dan mengurangi risiko terjadinya kemun-duran fungsi otot yang menyebabkan gangguan keseimbangan pada lansia umumnya. Tingkat kemandirian sangat diperlukan bagi lansia karena dengan mandiri lansia dapat melakukan aktivitasnya sendiri tanpa bantuan orang lain dan dapat memperkuat sendi-sendinya sehingga risiko jatuh sedikit teratasi.

Kemandirian memang diperlukan untuk tetap produktif di usia lanjut. Teori self efficacy menyatakan perlu adanya rasa percaya diri dan aman dalam melakukan aktivitas yang berhubungan dengan ketidaktergantungan dalam aktivitas sehari-hari. Dengan self efficacy seorang lansia memiliki keberanian dalam melakukan aktivitas dan mencegah ketergantungan (Martono H \& Pranaka K, 2009).

Pemberian asuhan keperawatan pada lansia saat ini menekankan pada peningkatan kesejahteraan lansia tidak hanya berorientasi pada perawatan akut. Kesehatan pada lansia merupakan interaksi antara faktor fisik, fungsional dan psikososial. Lansia tidak perlu bebas dari penyakit secara total, namun yang terpenting adalah lansia mampu hidup dan berfungsi maksimal dalam masyarakat untuk melatih kepercayaan diri dan otonomi. Berdasarkan hal tersebut ada dua peran penting perawat dalam keperawatan lansia yaitu perlindungan kesehatan dan promosi kesehatan. Aktifitas promosi kesehatan yang tepat bagi lansia adalah aktivitas fisik, mental, dan sosial secara teratur, nutrisi yang adekuat, pengendalian berat badan dan manajemen stres. Sedangkan perilaku perlindungan kesehatan adalah aktivitas yang menekankan pada pencegahan terhadap berkembangnya penyakit tertentu dan faktor risikonya. Olahraga teratur dan pembatasan diet merupakan perilaku untuk melindungi kesehatan (Stanley M \& Berae PG, 2007).

Sebuah penelitian menyatakan pentingnya aktivitas mental dan fisik yang berkesinambungan untuk mencegah kehilangan dan pemeliharaan kesehatan sepanjang kehidupan manusia. Dengan melakukan beberapa bentuk aktivitas aerobik selama minimal 20 menit, tiga atau empat kali seminggu, dengan periode pemanasan dan pendinginan, memungkinkan lansia untuk hidup dengan kondisi kesehatan yang baik ditahun-tahun selanjutnya. Bahkan dengan melakukan aktivitas sekecil apapun yang dilakukan di luar rumah, dapat meningkatkan sikap, mengurangi stres, menjadikan tidur lebih baik, dan mencegah depresi. Berjalan di luar atau disekitar rumah yang dilakukan dua 
Mashudi, Hubungan Kualitas Tidur dan Tingkat Kemandirian Activity of Daily Living dengan Risiko Jatuh Pada Lanjut Usia di Puskesmas Simpang IV Sipin Kota Jambi

atau tiga kali sehari lebih baik daripada hanya duduk di dalam rumah sepanjang hari. Teori aktivitas sosial mengemukakan bahwa lansia yang mengalami penuaan yang optimal akan tetap aktif dalam kehidupan sosial mereka (Stanley M \& Berae PG, 2007).

\section{SIMPULAN}

Ada hubungan antara kualitas tidur dan tingkat kemandirian dalam melakukan ADL dengan risiko jatuh pada lansia di puskesmas Simpang IV Sipin Kota Jambi. Perawat dapat mengajarkan lansia bagaimana mencegah jatuh dengan mengajarkan teknik yang aman untuk berpindah, mengambil sesuatu secara tepat, membungkuk, menghin-dari gerakan yang tergesa-gesa atau mendadak, waktu beraktivitas yang tepat, dan penggunaan obat yang benar. Perawat perlu mengidentifikasi penyebab gangguan tidur dan penanganan yang tepat sesuai penyebab gangguan tidur yang dialami.

Menjalankan program lansia sehat yang terdiri atas kegiatan penyuluhan kesehatan maupun aktivitas latihan rutin. Program latihan dapat berupa senam lansia, jalan santai, program latihan keseimbangan, yang dilakukan 2 hingga 3 kali seminggu secara teratur.

\section{DAFTAR PUSTAKA}

Dahlan MS. (2012). Statistik untuk kedokteran dan kesehatan: deskriptif, bivariat, dan multivariat. Edisi 5. Jakarta: Salemba Medika

Defi, Sari, Wulan. (2012). Hubungan hasil pemeriksaan tes timed up and go dengan kejadian jatuh pada lansia di desa turgo rejo harjobinangun: studi cross-sectional (Skripsi). Jakarta: Universitas Islam Indonesia

Dewi SR. (2014). Buku ajar keperawatan gerontik. Yogya karta: Deepublish

Ediawati E. (2012). Gambaran tingkat kemandirian dalam activity of daily living dan risiko jatuh pada lansia di panti sosial tresna werdha budi mulia 01 dan 03 jakarta timur: studi cross-sectional (Skripsi). Jakarta FIK UI

Farabi A. (2007). Hubungan tes "time up and go" dengan frekuensi jatuh pasien lanjut usia: studi cross-sectional (Skripsi). Semarang: Bagian Ilmu Penyakit Dalam FK Universitas Diponegoro

Flowerwnty DD. (2015). Pengaruh therapeutic exercise walking terhadap kualitas tidur klien dengan penyakit paru obstruksi kronik (PPOK) di poli spesialis paru RSP Kabupaten Jember. Jurnal Skripsi. Program Studi Ilmu Keperawatan Universitas Jember

Jayanti IGP. (2016) Demografi populasi penduduk lanjut usia di dunia dan indonesia. 10 April 2016. http://www.slideshare.net/mobile/gustiputrijayanti /prevalensi-lansia-di-dunia-dan-indonesia[diakses 19 Mei 2016].
Maryam RS, Ekasari MF, Rosidawati, Jubaedi A, Batubara I. (2008). Mengenal usia lanjut dan perawatannya. Jakarta: Salemba Medika

Martono H, Pranaka K, (2009). editor. Buku ajar Boedhi-Darmojo geriatri. Edisi ke-4. Jakarta: Balai Penerbit FKUI

Mubarak WI. (2008). Buku ajar kebutuhan dasar manusia : teori \& aplikasi dalam praktik. Jakarta: EGC

Ningrum DNP. (2011). Hubungan ketergantungan dalam activity of daily living ( $A D L)$ dengan tingkat depresi pada lansia di PSTW unit Budhi Luhur Yogyakarta tahun 2011. Jurnal Skripsi. Program Pendidikan Ners Program Studi Ilmu keperawatan. Stikes 'Aisyiyah Yogyakarta

Notoatmodjo S. (2010). Metodologi penelitian kesehatan. Jakarta: Rineka Cipta

Nugroho W. (2014). Keperawatan gerontik \& geriatrik. Edisi 3. Jakarta: EGC

Potter, Patricia A.(2006). Buku ajar fundamental keperawatan: konsep, proses, dan praktik. Edisi ke-4. Jakarta: EGC

Pusat Komunikasi Publik Sekretariat Jenderal Kementerin Kesehatan RI. Pelayanan dan peningkatan kesehatan usia lanjut. 27 Mei 2015. http://www.depkes.go.id/article/print/1505270001 0/pelayanan-dan-peningkatan-kesehatan-usialanjut.html [diakses 19 Mei 2016].

Sari YP. (2015). Hubungan tingkat kemandirian aktivitas sehari-hari dengan risiko jatuh pada lansia di pstw unit budhi luhur kasongan bantul: studi cross-sectional (Skripsi). Yogyakarta: PSIK Sekolah Tinggi Ilmu Kesehatan 'Aisyiyah

Stanley M, Beare PG. (2007). Buku ajar keperawatan gerontik. Edisi 2. Jakarta: EGC

Sugiyono. (2010). Metodologi penelitian pendidikan pendeka-tan kuantitatif, kualitatif, dan $R \& D$. Bandung: Alfabeta

Sulistyarini ND. (2015). Hubungan antara kualitas tidur dengan keseimbangan tubuh pada lansia di kecamatan turi: studi cross-sectional (Skripsi). Yogyakarta: PSIK Fakultas Kedoteran UGM

Supriyadi E, (2014). editor. Ada 178.302 Lansia di Provinsi Jambi. Antara Jambi. 25 Agt 2014;1. http://m.antarajambi. com/berita/304506/ada178302-lansia-di-provinsi-jambi [diakses $19 \mathrm{Mei}$ 2016].

Tamher S, Noorkasiani. (2009). Kesehatan usia lanjut dengan pendekatan asuhan keperawatan. Jakarta: Salemba Medika

Utomo B, Takarini N. (2009). Uji validitas kriteria time up and go (TUG) sebagai alat ukur keseimbangan pada lansia. Jurnal Fisioterapi. Vol 9. No 2. Okt 2009. 